\title{
Evaluation of Groundwater Potential of Baikin Ondo State Nigeria Using Resistivity and Magnetic Techniques: A Case Study
}

\author{
A. A. Adepelumi", O. B. Akinmade, Fayemi. O \\ Department of Geology, Obafemi Awolowo University, Ile-Ife, Nigeria \\ *Corresponding author: adepelumi@gmail.com
}

Copyright (C) 2013 Horizon Research Publishing All rights reserved.

\begin{abstract}
A combined electrical resistivity and Magnetic surveys was carried out to locate fissured zones and associated groundwater-bearing media at Baikin Area in Ondo State, Nigeria that is known to have acute groundwater supply shortage. One Hundred (100) Vertical Electrical Soundings were acquired along ten traverses using the Schlumberger array with maximum half current electrode spacing $(\mathrm{AB} / 2)$ of $200 \mathrm{~m}$. Magnetic data were acquired along the traverses at station interval of $10 \mathrm{~m}$ using the Proton Precession Magnetometer. Four geologic layers were delineated. These include the topsoil, weathered layer, fractured basement and fresh basement bedrock. The thickness of the topsoil ranged from 0.2 to $1.1 \mathrm{~m}$ while the resistivity values varied from 29 to $455 \Omega \mathrm{m}$. The weathered layer thickness varied between 0.2 and $12.6 \mathrm{~m}$ while its resistivity ranged between 13 and $307 \Omega \mathrm{m}$. The fractured basement delineated had resistivity value of $61 \Omega \mathrm{m}$. The fresh basement resistivity ranged between 941 and $\alpha \Omega \mathrm{m}$. The overburden thickness ranged between 1.1 and $12.9 \mathrm{~m}$. The weathered and fractured aquifers constituted the main aquifer units. Aquifer thickness varied between 0.2 and 12.6 m. Quasi 3D magnetic models also showed that depth to bedrock in the study area was shallow. The study concluded that the groundwater potential of Baikin Area was generally low.
\end{abstract}

Keywords Resistivity, Schlumberger, Groundwater, Aquifer, Fracture

\section{Introduction}

Water is essential to mankind in various ways. It has various uses in terms of domestic, agriculture and industrial purposes. It is an element of the landscape demanding rigorous scientific quantification and analysis [1]. Water occurs as both groundwater and surface water. Groundwater is a significant part of the hydrologic cycle containing $21 \%$ of the earth freshwater.

The early part of the 20th century saw a rapid expansion of the exploration of groundwater supplies due to industrialization and increase in demand for water [1]. When groundwater moves slowly in the crust along cracks, fractures and faults, it acquires different mineral or chemical constituents. These chemical constituents are derived from direct contact with the underlying bedrock.

Groundwater is the largest available reservoir of fresh water. Most fresh water is locked away as ice in the polar ice caps, continental ice sheets and glaciers. Water in rivers and lakes account for less than $1 \%$ of the World's fresh water reserves [2]. It is among the natural resources bestowed to the human race. Observation shows that groundwater comes from precipitation such as rain, snow, sheet and hail that soak into the ground and become the groundwater responsible for the spring, wells and boreholes [3].

The search for groundwater requires detailed geophysical investigations. This study is focused on assessing the groundwater potential of Baikin area using Integrated Resistivity and Magnetic methods. The vertical electrical sounding method was chosen for Baikin because the instrumentation is simple; field logistics are easy and straightforward and the analysis of data is less tedious and economical $[4,5,6,7]$.

The resistivity method has been used successfully in investigating groundwater potential. [3] used the method to investigate the aquifer characteristics and groundwater potential in Kwale, Delta State, Nigeria. [8] employed the same method to explore for groundwater in a sedimentary environment. [9] adopted the method to delineate aquifer units and established the thickness and depth of water bearing formation. [10] determined the groundwater potential at Obudu basement area using the resistivity method. [11] utilized the resistivity method to investigate the groundwater potential in Emu Kingdom.

The aim of the present study is to investigate the groundwater potential of Baikin area, Ondo State, because of increasing demand for water by the inhabitants. 


\section{Geology and Hydrogeology}

The study area is Baikin Village in Ondo East Local Government Area of Ondo State, Southwestern Nigeria (Fig. 1). It lies between latitudes $7^{\circ} 10^{\prime} 39^{\prime \prime}$ and $7^{\circ} 10^{\prime} 51^{\prime \prime} \mathrm{N}$ and longitudes $4^{\circ} 59^{\prime} 35^{\prime \prime}$ and $4^{\circ} 59^{\prime} 49^{\prime \prime}$ E. It can be accessed through the Ondo-Akure express-way. It has a network of both tarred and untarred roads as well as footpaths. The terrain is moderately undulating with topographic elevation ranges from $262 \mathrm{~m}$ to $264 \mathrm{~m}$ above sea level.

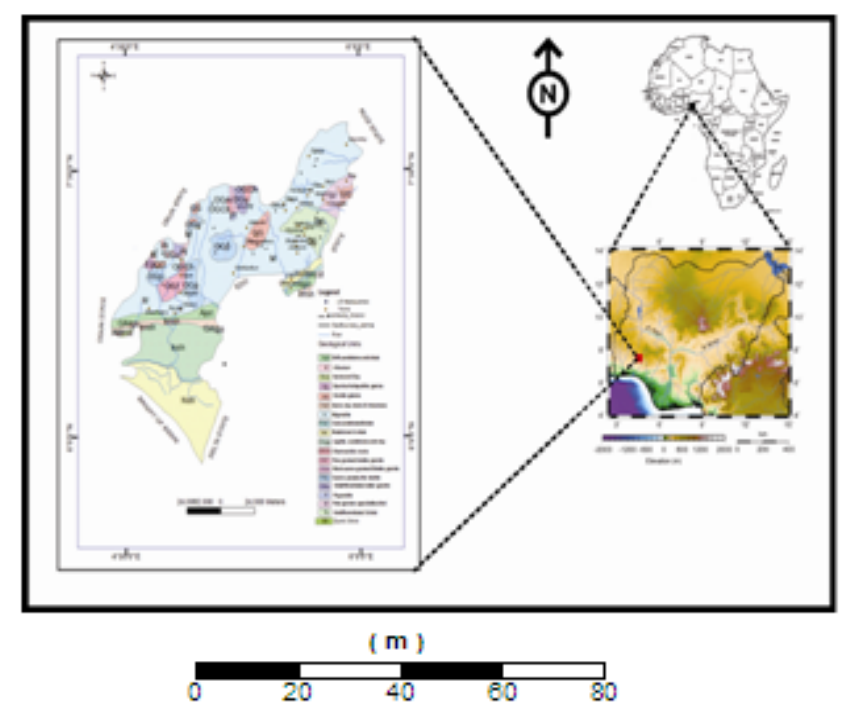

Figure 1. Geological map showing the Study Area.

The Area falls within the humid tropical climatic zone which has prominent wet and dry seasons. A typical wet season extends from April to October, while the dry season extends from November to March. Annual rainfall ranges between $100 \mathrm{~mm}$ and $1500 \mathrm{~mm}$, with average wet days of about 100. Annual temperature varies between $180 \mathrm{C}$ and 340C [12].

The study area is underlain by the Precambrian Basement complex rocks of Southwestern Nigeria [13]. The local geologic units identified in the study area are the Migmatitic-Gneisses. They are composed of three main components namely: Early Gneiss, Mafic- Ultramafic Bands and Granitic or Felsic Component (Fig. 1).

In basement complex rock areas, storage and transmission of groundwater is made possible through the presence of discontinuities within the rock media. These discontinuities can occur in the form of fractures, joints (and joint systems), faults, lineations and cracks within the rock masses [14]. Groundwater is known to accumulate within the weathered and /or fractured basement zones $[15,16]$.

The nature and extent of weathering vary considerably, depending upon the presence of fractures at the surface [17, 18]. [19], pointed out that the saturated weathered and or fractured / jointed zones constitute the main aquifer unit in basement complex hard rocks. The static water level observed in the area is less than $10 \mathrm{~m}$. Estimated Permeability and Transmissivity of the area range from 0.53 to $2.39 \mathrm{~m} / \mathrm{s}$ and 0.33 to $6.69 \mathrm{~m} 2 / \mathrm{s}$ respectively.

\section{Data Acquisition and Analysis}

The instrument used in the present study included the Syscal Junior Resistivity meter for measuring ground resistivity, a pair of current and pair of potential electrodes for transmitting current into the ground and for measuring the potential difference at the surface respectively. The set up was made possible by two sets of cable reels that were connected to both the current and potential electrodes. The electrodes were driven into the ground with the aid of geologic hammers. The current and potential electrodes were maintained at predetermined distance (electrode spacing) depending on the purpose of the survey, the techniques employed and the method adopted for the investigation.

One Hundred (100) Vertical Electrical Sounding data were acquired with the aid of Syscal Junior Resistivity Meter along ten traverses (Fig. 2) using the Schlumberger array with maximum half current electrode spacing $(\mathrm{AB} / 2)$ of 200 $\mathrm{m}$. The VES data were presented as depth sounding curves. The partial curve matching interpretation method was adopted and the results (layer resistivities and thickness) were used as starting model parameters for a fast computer-assisted 1-D forward modeling.

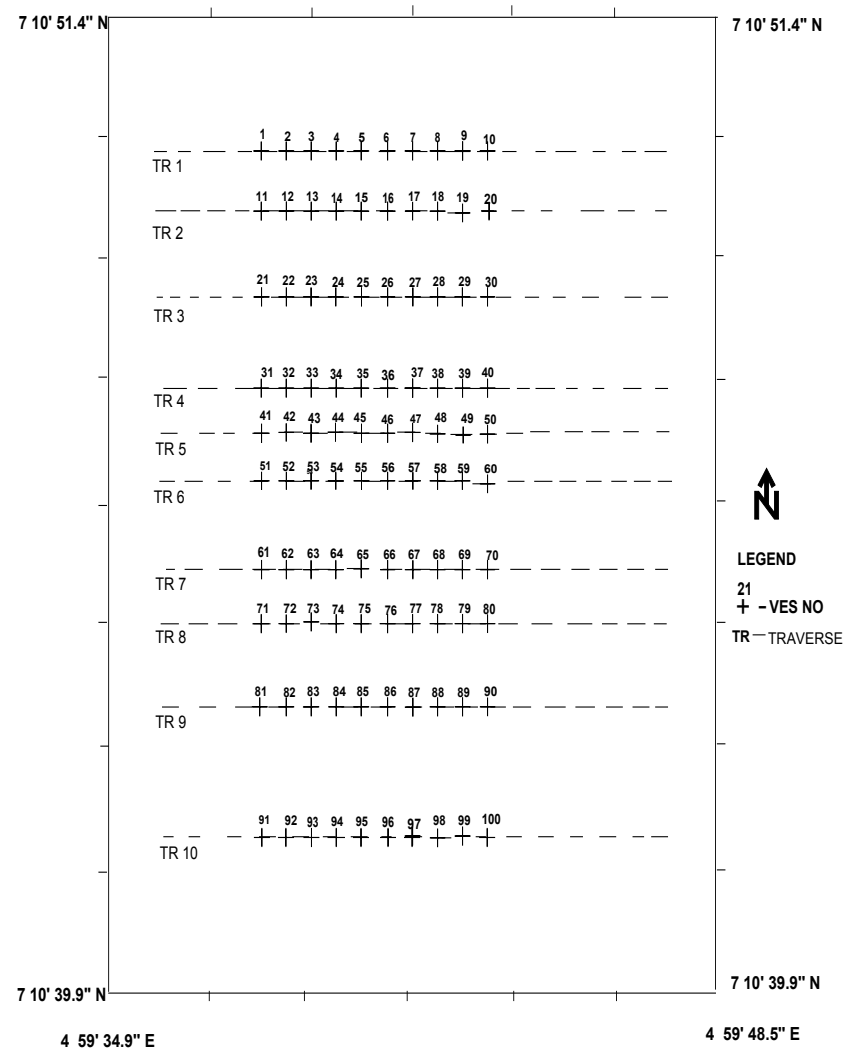

Figure 2. Map showing the layout of Magnetic Traverses and VES Locations in the area.

Magnetic data were acquired along ten traverses in the E-W direction (Fig. 2) at station interval of $10 \mathrm{~m}$ using the 
Proton Precision Magnetometer which measures the total intensity of the earth's magnetic field. Readings were not taken in the vicinity of metallic objects such as railways lines, cars, roads, fencing, houses which might perturb the local magnetic field. For similar reason, operator of magnetometer should not carry metallic objects. Readings were acquired along the same traverses with electrical resistivity survey. The raw magnetic data were corrected for diurnal variation. The earth's normal magnetic field of the study area was calculated using the International Geomagnetic Reference Field (IGRF) and subtracted from the diurnal corrected observed values to produce the residual geomagnetic field. Quasi 3D modeling of the residual geomagnetic field data was also carried out.

\section{Results and Discussion}

The results, which evolved from the Magnetic and VES data interpretation are presented as profiles, geoelectric sections and maps. The total and residual fields magnetic anomaly maps of the study area are presented as Figure 3 and Figure 4 respectively.

2.75 D (Quasi-3D) models of the subsurface (Figure 5) generated from the magnetic data using the Winglink software indicate variation in magnetic susceptibility of the rock units in the area. The magnetic models also showed that the depth to bedrock in the study area was shallow.

The VES data obtained were interpreted quantitatively by way of partial curve matching and computer iteration

technique. From the interpretation and modeling results, the geoelectric parameters of the subsurface layers were deduced as presented in Table 1 below.

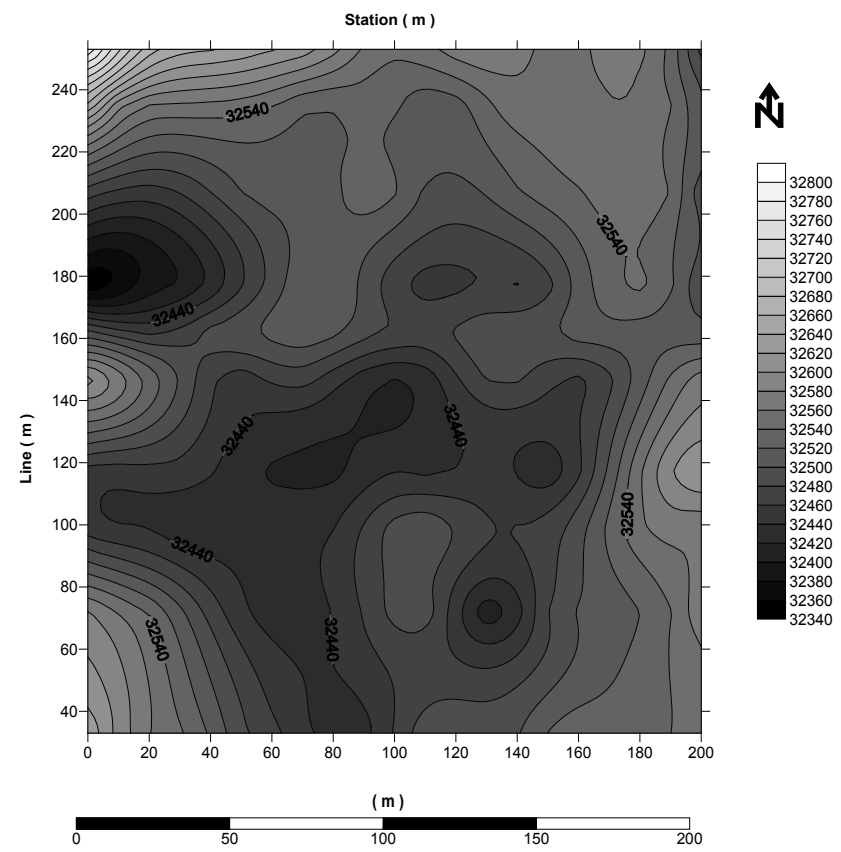

Figure 3. Total Field Magnetic Anomaly Map

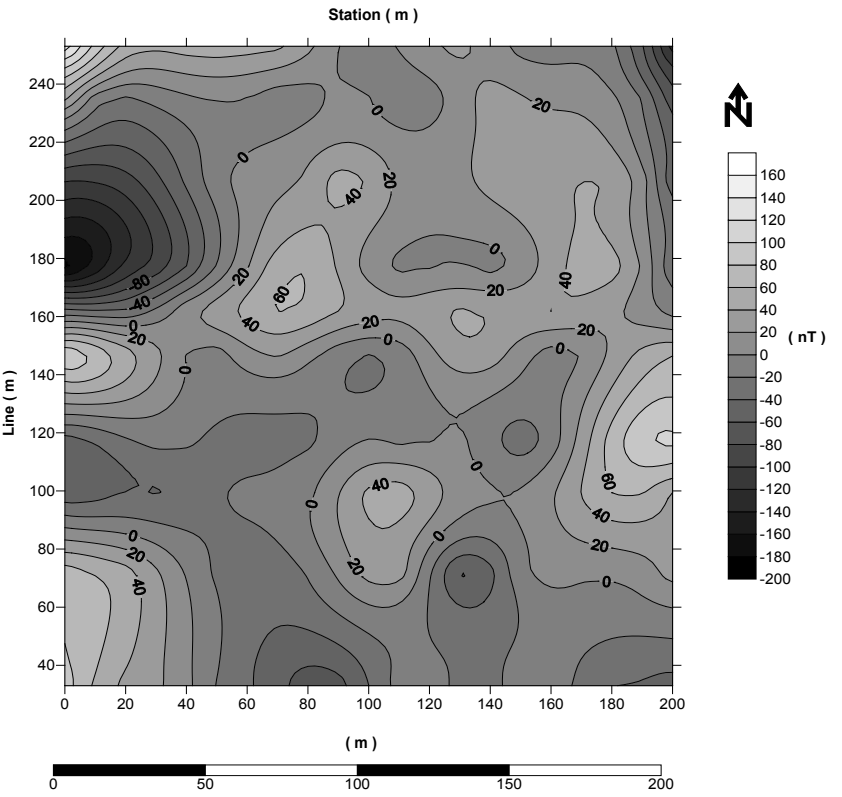

Figure 4. Residual Field Magnetic Anomaly Map.
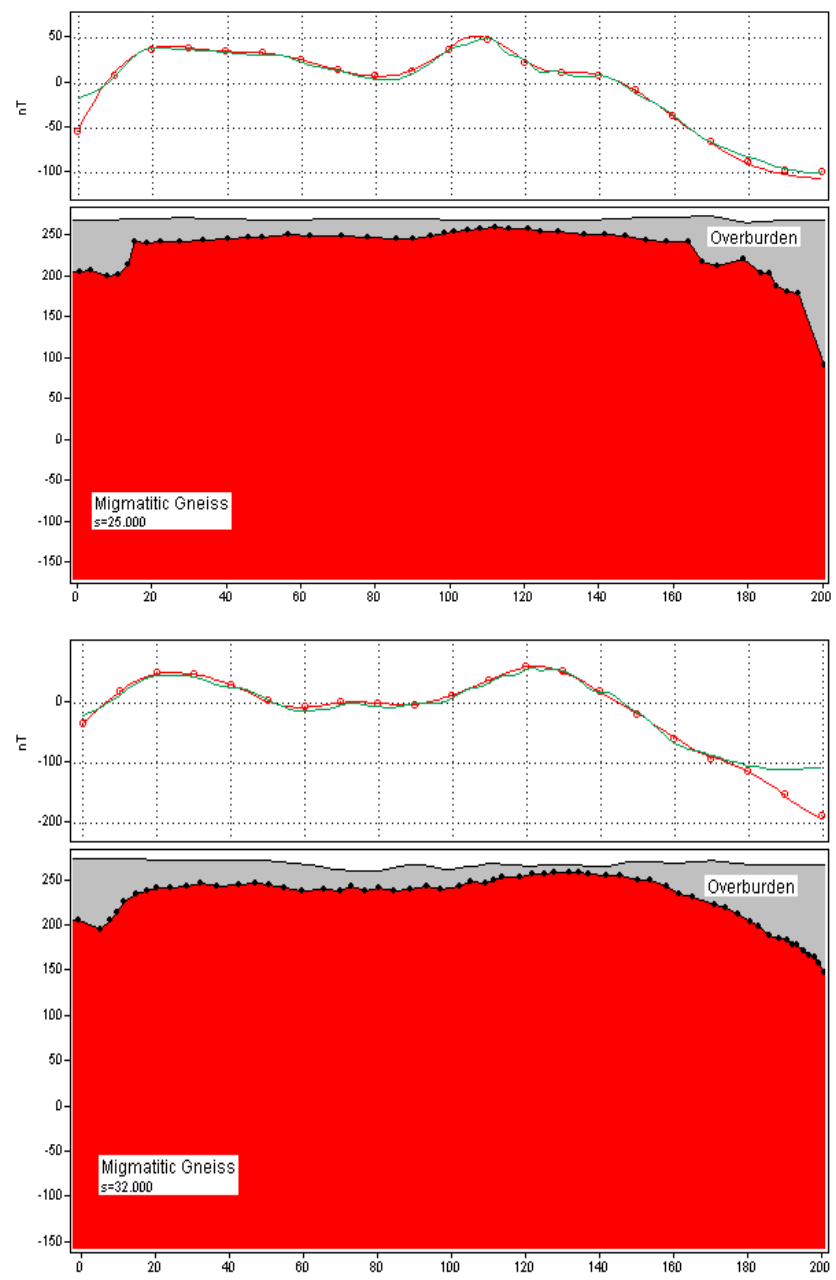

Figure 5. Quasi-3D Magnetic Models of Along Traverse 3 and 4 (Red Line- Observed magnetic field; Green Line-Calculated magnetic field). 
Table 1. VES Interpretation Results

\begin{tabular}{|c|c|c|c|c|}
\hline VES Stations & $\begin{array}{c}\text { Traverse } \\
\text { Lines } \\
\end{array}$ & $\begin{array}{c}\text { Thickness (m) } \\
\mathrm{h} 1 / \mathrm{h} 2 / \mathrm{h} 3 \ldots\end{array}$ & $\begin{array}{c}\text { Resistivity (ohm-m) } \\
\rho 1 / \rho 2 / \rho 3 / \ldots \\
\end{array}$ & $\begin{array}{c}\text { Type } \\
\text { Curves }\end{array}$ \\
\hline 1 & 1 & $0.8 / 1.6$ & $260 / 175 / 2621$ & $\mathrm{H}$ \\
\hline 3 & 1 & $0.3 / 4.9$ & $132 / 94 / 68109$ & $\mathrm{H}$ \\
\hline 5 & 1 & $0.6 / 0.5$ & $247 / 31 / 2830$ & $\mathrm{H}$ \\
\hline 8 & 1 & $0.4 / 3.9$ & $338 / 299 / 1540$ & A \\
\hline 10 & 1 & $0.4 / 2.8$ & $134 / 107 / 2979$ & $\mathrm{H}$ \\
\hline 13 & 2 & $0.8 / 10.1$ & $50 / 94 / 4644$ & A \\
\hline 18 & 2 & $0.5 / 8.0$ & $128 / 178 / 2957$ & A \\
\hline 20 & 2 & $0.9 / 2.8$ & $139 / 190 / 3085$ & A \\
\hline 21 & 3 & $0.3 / 2.3$ & $30 / 89 / 1775$ & A \\
\hline 25 & 3 & $0.5 / 6.5$ & $97 / 130 / 11460$ & A \\
\hline 29 & 3 & $0.4 / 4.9$ & $60 / 55 / 1791$ & $\mathrm{H}$ \\
\hline 31 & 4 & $0.6 / 1.5$ & $61 / 43 / 6694$ & $\mathrm{H}$ \\
\hline 33 & 4 & $0.3 / 2.2$ & $62 / 63 / 9078$ & A \\
\hline 47 & 5 & $0.9 / 7.2$ & $180 / 78 / 23422$ & $\mathrm{H}$ \\
\hline 49 & 5 & $0.3 / 12.6$ & $182 / 144 / 25592$ & $\mathrm{H}$ \\
\hline 51 & 6 & $0.7 / 2.3$ & $80 / 47 / 49363$ & $\mathrm{H}$ \\
\hline 57 & 6 & $0.6 / 6.0$ & $78 / 64 / 25714$ & $\mathrm{H}$ \\
\hline 64 & 7 & $1.0 / 10.1$ & $344 / 210 / 31525$ & $\mathrm{H}$ \\
\hline 72 & 8 & $0.8 / 6.3$ & $178 / 246 / 19904$ & A \\
\hline 75 & 8 & $0.9 / 1.1$ & $74 / 51 / 16181$ & $\mathrm{H}$ \\
\hline 76 & 8 & $0.6 / 5.5$ & $46 / 59 / 35690$ & A \\
\hline 78 & 8 & $0.6 / 5.4$ & $98 / 56 / 2928$ & $\mathrm{H}$ \\
\hline 80 & 8 & $0.9 / 3.3 / 12.2$ & $66 / 29 / 24032 / 61$ & $\mathrm{HK}$ \\
\hline 81 & 9 & $0.8 / 4.4$ & $164 / 196 / 2103$ & $\mathrm{~A}$ \\
\hline 83 & 9 & $0.7 / 0.8$ & $329 / 135 / 7729$ & $\mathrm{H}$ \\
\hline 84 & 9 & $0.6 / 5.8$ & $196 / 287 / 1925$ & A \\
\hline 90 & 9 & $0.4 / 2.7$ & $83 / 42 / 1324$ & $\mathrm{H}$ \\
\hline 94 & 10 & $0.6 / 0.6$ & $238 / 94 / 14251$ & $\mathrm{H}$ \\
\hline 96 & 10 & $0.9 / 8.1$ & $51 / 105 / 10935$ & A \\
\hline 97 & 10 & $0.4 / 5.7$ & $67 / 55 / 4840$ & $\mathrm{H}$ \\
\hline 99 & 10 & $0.3 / 7.2$ & $146 / 89 / 105996$ & $\mathrm{H}$ \\
\hline 100 & 10 & $0.7 / 2.2$ & $94 / 27 / 941$ & $\mathrm{H}$ \\
\hline
\end{tabular}

\subsection{Geoelectric/Lithologic Characteristics and Aquifer Delineation}

Figure 6 shows typical geoelectric curves corresponding to VES data from the study area. The VES data revealed three type curves - A, H and HK. The dominant curve type was the $\mathrm{H}$ curve constituting fifty-seven percent of the VES curves. There are forty- two A curves and one HK curves. Figures 7 (a-e) shows some of the geoelectric cross sections generated in the W-E and N-S directions. The sections show the subsurface variation in electrical resistivity along the profiles and also attempt to correlate the geoelectric sequence across the profiles. 

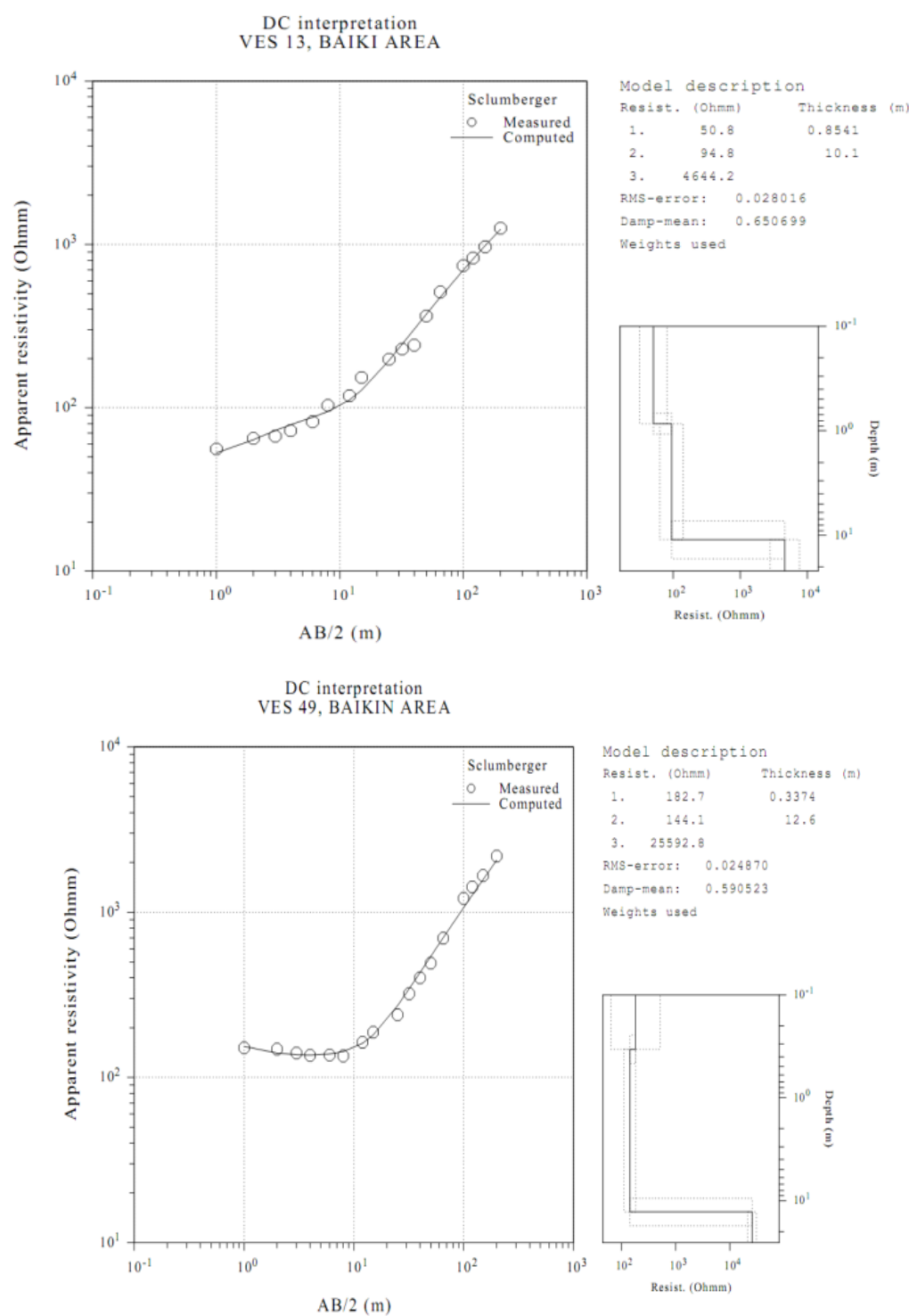

Model description

Resist. (Ohmm) Thickness (m)

$\begin{array}{lll}\text { 1. } & 182.7 & 0.3374\end{array}$

2. $144.1 \quad 12.6$

325592.

RMS-error: $\quad 0.024870$

Damp-mean: $\quad 0.590523$

Weights used

C interpretation

VES 64 , BAIKIN AREA

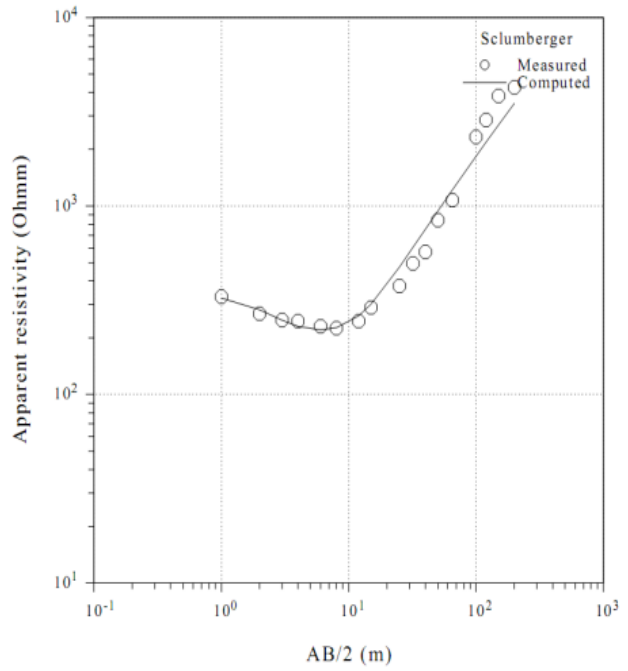

Model description

Resist. (Ohmm) Thiekness (m)

1. $346.9 \quad 1.0$

3. 31525.7

RMS-error: $\quad 0.058529$

Damp-mean: 0.625171

Weights used

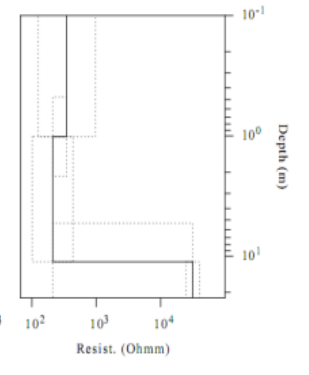




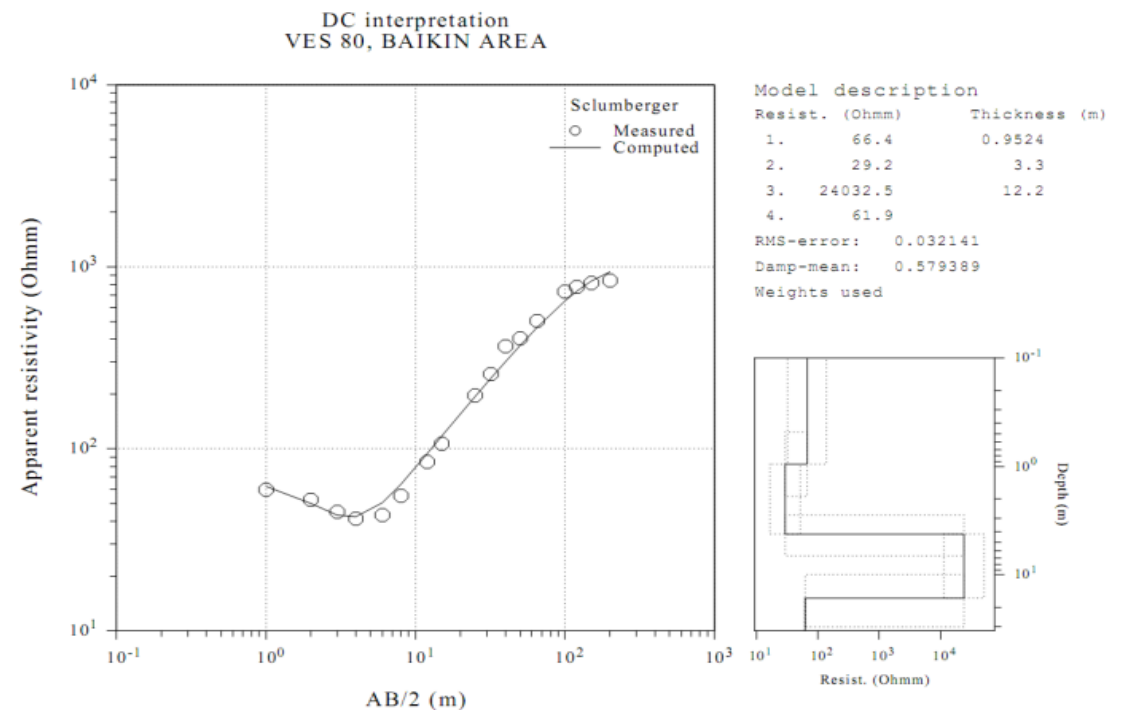

Figure 6. Typical VES curves from Baikin (VES 13, 49, 64 AND 80)

W

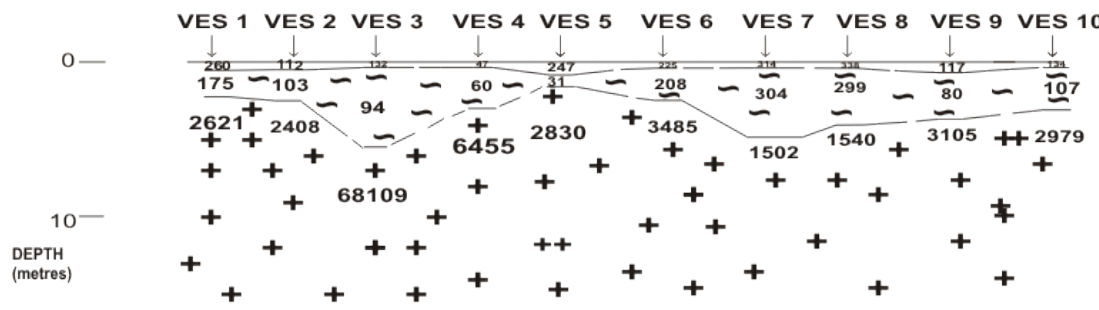

$20-$

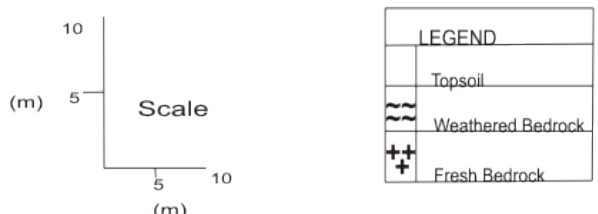

Figure 7(a). Geoelectric Section 1

W

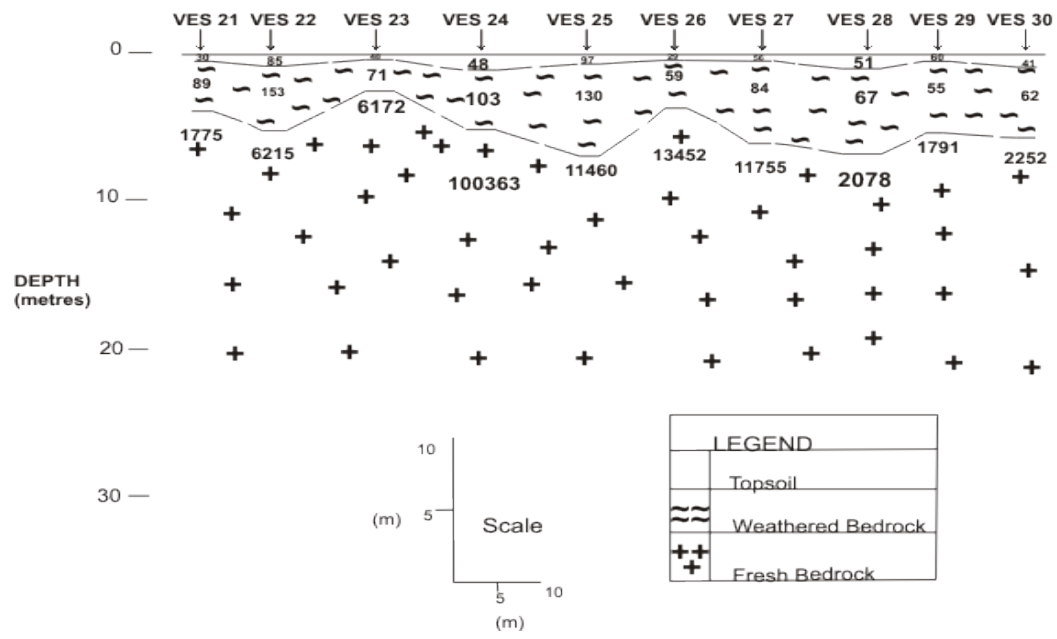

Figure 7(b). Geoelectric Section 2 


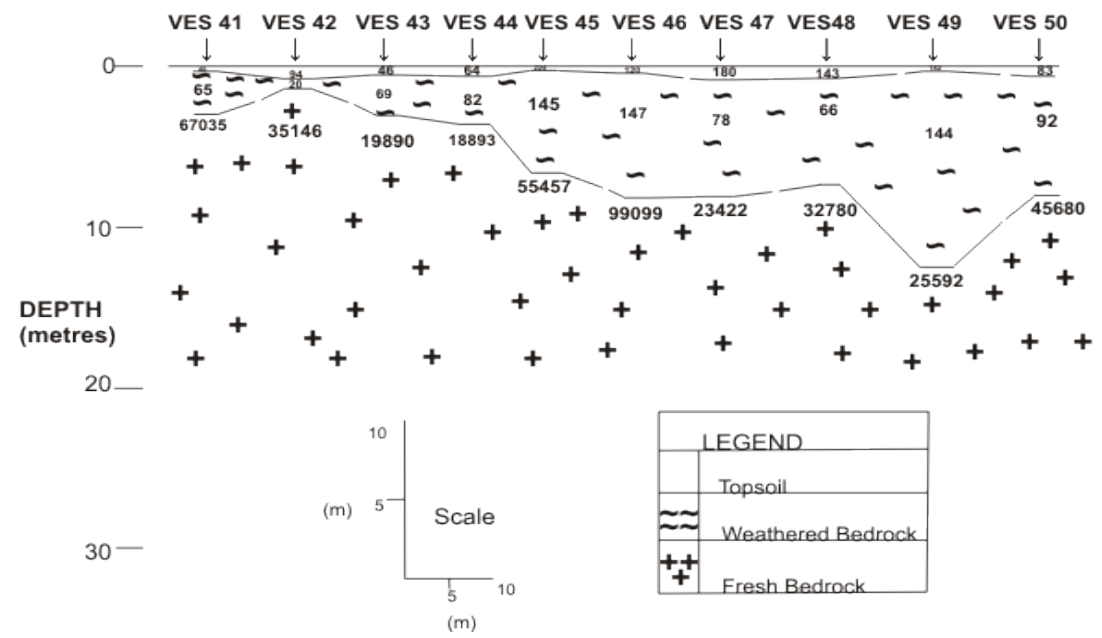

Figure 7(c): Geoelectric Section 3

N

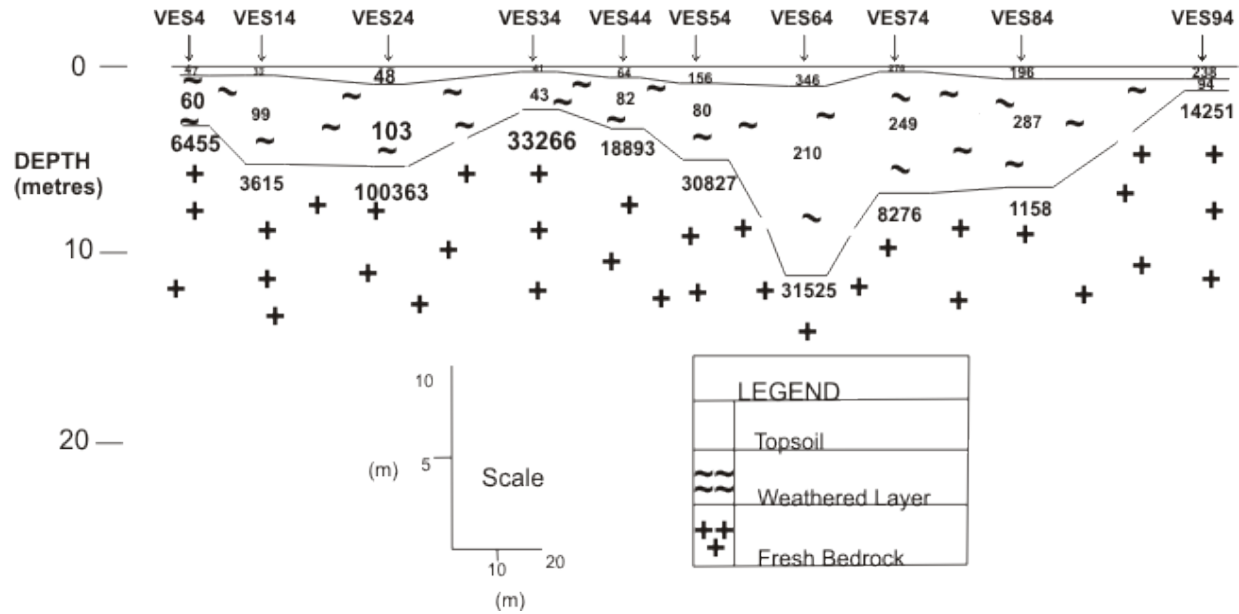

Figure 7(d). Geoelectric Section 4

W

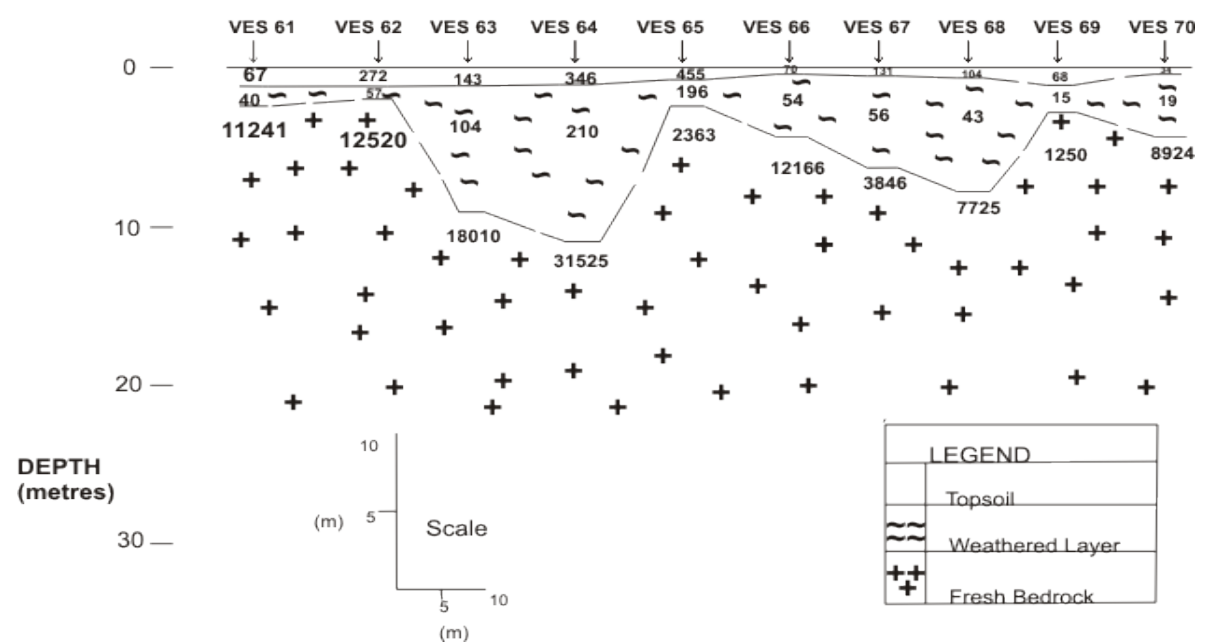

Figure 7(e). Geoelectric Section 5 


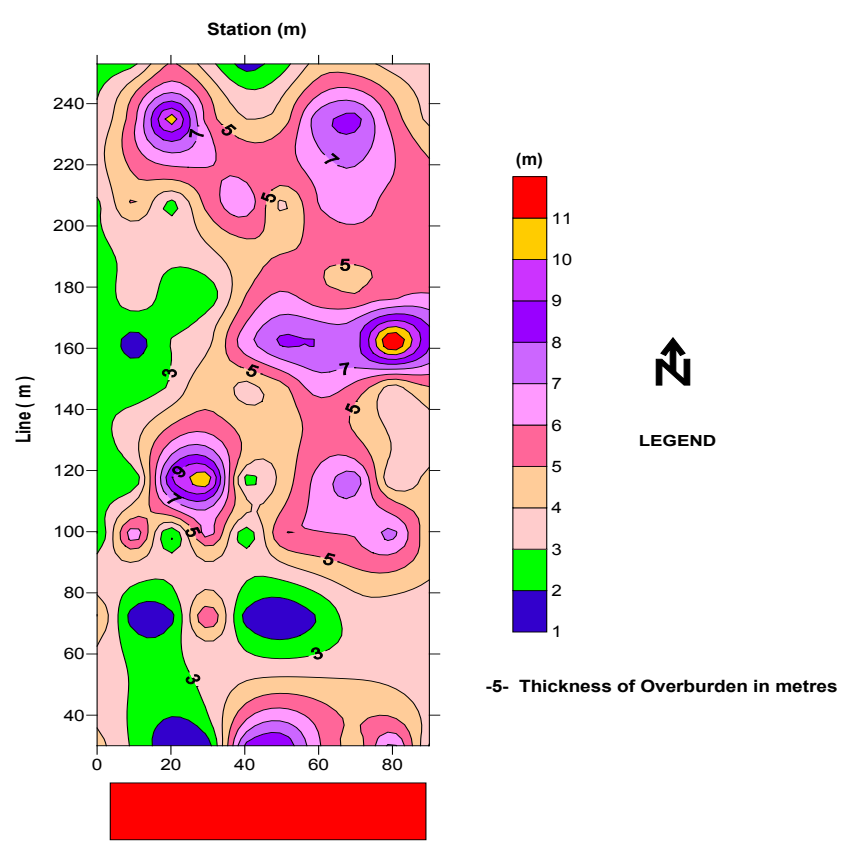

Figure 8. Isopach Map of Baikin Area

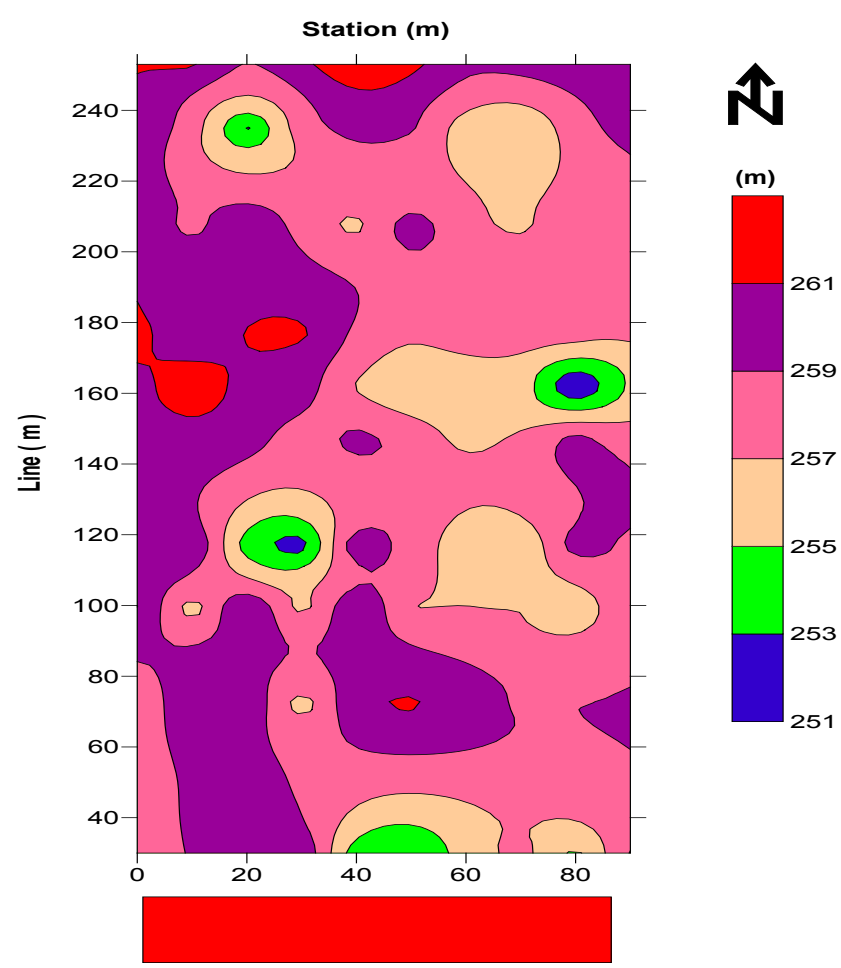

Figure 9. Bedrock Relief Map of Baikin Area

The significance of the bedrock relief map (Figure 9) is its reflection of the bedrock topography and structural disposition [20]. The bedrock topography of the area is predominantly ridges as a result of its thin overburden. The Groundwater potential map (Figure 10) was generated based on the aquifer thicknesses delineated across the VES locations. These thicknesses were plotted and contoured. The map reveals that aquifer thickness varied from 0.3 to $12.6 \mathrm{~m}$.

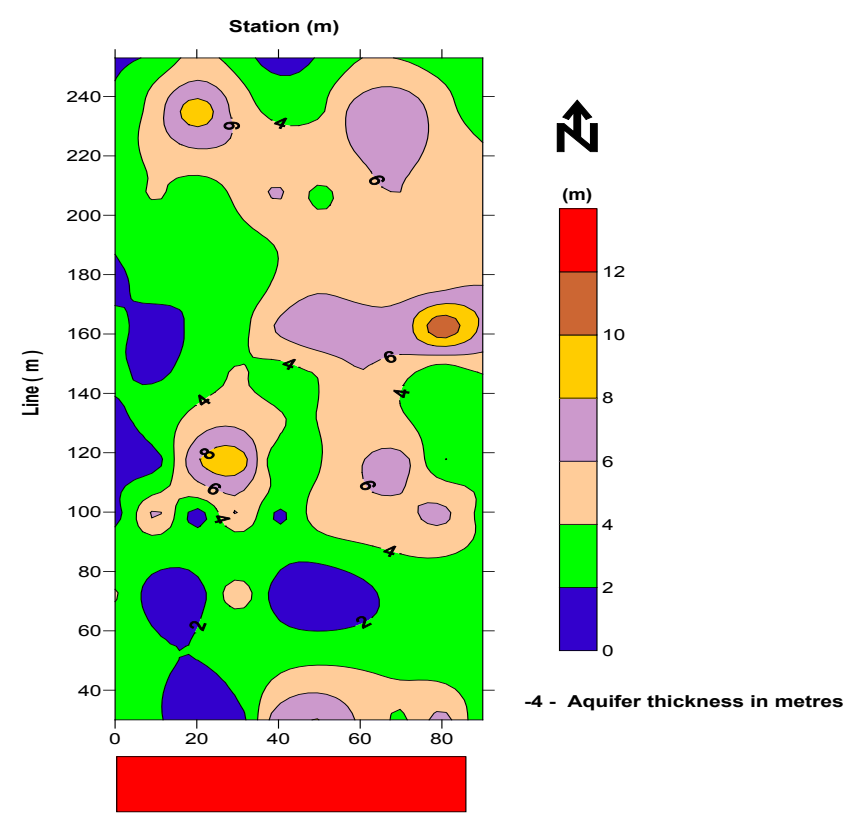

Figure 10. Groundwater Potential Map of Baikin Area

\section{Conclusion}

The vertical electrical resistivity and magnetic surveys carried out Baikin area have enhanced the knowledge of the hydrogeology of Ondo State which will assist groundwater development and management activities.

Based on the main findings of this study, it can be concluded that the development of groundwater resources should be carried out at VES Stations 13, 49, 64 and 80 where favorable condition for accumulation of groundwater exist.

Finally, successful groundwater exploration requires a thorough geologic and geophysical surveys so as to gain deep insight of groundwater occurrences in the area. Therefore, an integrated geological and geophysical exploration technique should be employed.

\section{Acknowledgements}

Profound gratitude goes to Dr Jung Ho Kim for making the GPR processing software (Radpro) available to the Department of Geology, Obafemi Awolowo University, Nigeria.

\section{REFERENCES}

[1] Brown, R. L. and Parizek. R. R. Shallow Ground Water Flow Systems beneath Strip and Deep Coal Mines at Two Sites, Clearfield County, Pennsylvania. The Pennsylvania State Univ., University Park. Special Report of Research SR-84. 207 pp, 1971.

[2] United Nations Educational, Scientific, and Cultural 
Organization. World Water Balance and Water Resources of the Earth. 1996.

[3] Oseji, J. O., Atakpo, E. A. and Okolie, E. C. Geoelectric investigation of the aquifer characteristics and groundwater potential in Kwale, Delta state, Nigeria. J. Applied Sci. Environ. Mgt., 9: 157-160, 2005.

[4] Ekine A. S, and Osobonye G. T. Surface Geoelectric Sounding for the determination of Aquifer Characteristics in parts of Bonny Local Government Area of River State". Niger. J. Phys. 85: 93-97, 1996.

[5] Ako, A. O. and Olorunfemi, M. O. Geoelectric survey for groundwater in the Newer Basalts of Vom Plateau State. Nig Journal of Mining and Geology Vol. 25 (1\& 2) pp 247-450, 1989.

[6] Etu-Efeotor, J. O, Akpokodje E .G. Aquifer systems of the Niger Delta. Niger. J. Min. Geol. 26(2): 279-284, 1990.

[7] Okolie E. C, Osemeikhian JEEA, Oseji J. O and Atakpo, E. Geophysical Investigation of the source of River Ethiope in Ukwuani Local Government area of Delta State. Niger.Inst. Phys. (17): 21-26, 2005.

[8] Emenike E .A. "Geophysical Exploration for Groundwater in a Sedimentary Environment": A case study from Nanka over Nanka formation in Anambra Basin, Southeastern Nigeria. Global J. Pure Appl. Sci. 7(1): 97- 110, 2000.

[9] Ako B. D. and Osunde V.C. "Electrical Resistivity Survey of Kerri Formation darazo". Niger. J. Afr. Earth Sci. 5: 527-534, 1982.

[10] Okwueze E. E. "Preliminary Findings of the Groundwater Resources Potentials from a regional geoelectric survey of the Obudu basement area, Niger. Global J. Appl. Pure Sci. 2: 210-211, 1996.

[11] Oseji J. O. and Ujuanbi O. "Hydrogeophysical investigation of groundwater potential in Emu Kingdom, Ndokwa land of Delta State, Nigeria”. Int. J. Phys. Sci. 4(5): 275-284, 2009.

[12] IIoeje, N. P. A New Geography of Nigeria (New Revised Edition). Longman Group: London, UK. 32-45, 1980.
[13] Rahaman, M. A. Review of the basement geology of southwestern Nigeria. In C.A. Kogbe (Editor): Geology of Nigeria, Elizabethan Publishing Co., Lagos pp 41-58, 1976.

[14] Teme, S. C. and Oni, S. F. Detection of groundwater flow in fractured media through remote sensing techniques-some Nigeria cases. Journal of African Earth Sciences, Vol.12, No.3, pp 461-466, 1991.

[15] Olayinka, A. I. and Olorunfemi, M. O. Determination of geoelectrical characteristics in Okene area and implication for borehole siting. Journal of Mining and Geology, 28: 403-412, 1992.

[16] Olorunfemi, M. O. and Fasuyi, S. A. Aquifer types and the geoelectric /hydrogeological characteristics of part of the central basement terrain of Nigeria (Niger State). Journal of African Earth Sciences, 16 (3): 309-316, 1993.

[17] Satpathy, B. N. and Kanungo, D. N. Groundwater exploration in hard rock terrain: a case history. Geophysical Prospecting, 24: 725-736, 1976.

[18] Verma, R. K., Rao, M. K. and Rao, C.V. Resistivity investigation for groundwater in Metamorphic areas near Dhanbad India. Groundwater, 18(1): 46-55, 1980.

[19] Olorunfemi, M. O., Olarewaju, V. O. and Alade, O. On the electrical anisotropy and groundwater yield in basement complex area of S.W. Nigeria. Journal of African Earth Sciences, Vol.12, No.3, pp 467-472, 1991.

[20] Olorunfemi, M. O. and Okhue, E. T. "Hydrogeologic and Geoelectric Significance of a Geoelectric Survey at Ile-Ife, Nigeria". Journal of Mining and Geology. Vol. 23. pp 221-228, 1992

[21] Bala, A. E. and Ike, E.C. "The Aquifer of the Crystalline Basement Rocks in Gusau Area, Northwestern Nigeria". Journal of Mining and Geology. 37(2): 177-184, 2001.

[22] Omosuyi, G. O., Ojo J. S. and Enikanselu, P. A. 'Geophysical Investigation for Groundwater around Obanla-Obakekere in Akure Area within the Basement complex of South-Western Nigeria'. Journal of Mining and Geology. 39(2):109-116, 2003. 